\title{
Memories of Michael McDougall
}

\section{RichaRd ZWEIFEL AND Vic Holanda}

A memorial to CRP professor Michael McDougall was held at Cal Poly's Rotunda Lecture Room on Saturday, May 19, 2007. During the ceremony, fomer teaching colleague, Richard Zweifel and former student, Vic Holanda were invited by Mike's family to speak, share their memories, and help celebrate his life.

Richard Zweifel ASLA, is Associate

Dean, College of

Architecture and Environmental Design, Cal Poly San Luis Obispo.

\section{Remarks by Richard Zweifel}

I am grateful for the opportunity to help celebrate a life that has made such a positive difference in so many other lives. I am sure if we could each choose, we would have wanted to put any need for this tribute way into the future. Although my words will not be adequate, I want to express the College's sincere gratitude for Mike's many contributions to education and to Cal Poly. However, I mostly want to share a little of my own feelings for his gift.

Mike, along with "Texas" John Stuart, were my first officemates when I came to teach at Cal Poly in January 1973. As a young guy, who didn't have any teaching experience beyond TA work as a graduate student (and not a whole lot of life experience for that matter), I couldn't have had a better professional start because of these two and the other special people I came to know during those early years.

My real story is about Mike helping to contribute to my losing a job and starting to drink...let me explain.

I came to Cal Poly not because I had lofty goals of teaching-I just needed a job. I was waiting for a work permit to be able to start an urban design position I had accepted in Northern Ireland. When the permit finally came, it was because of what I learned and experienced from Mike and others that I chose to turn it down in order to stay teaching at Cal Poly. Mike helped to open my eyes to other possibilities, high professional standards, interdisciplinary work and so many other things. So, in a way, he really did cost me a job, but it was the best thing that could have ever happened. I lost a job and gained a career.

Mike truly knew a lot about a lot of things. What I found so special was that he took the time to mentor a young colleague (me). I doubt he ever even used the term "mentor"; he simply did all the right things to encourage, teach and share by example without making it seem like a lesson. Mike did what he did in such a wonderful way largely as a natural extension of his personality. He certainly had my attention and respect because of his extensive professional work (this guy really knew what he was doing), but what made such a difference, was his sincere interest in people and his infectious humor. Although the jokes have long since passed from my memory, his delivery and the twinkle in his eye will always be there. The more outrageous the punch line, the brighter his smile.

Mike's style was one of offering by example and real concern and not by giving instructions. I felt he really did take an interest in what I was doing... and perhaps should do.

Which brings me to the drinking part. Before knowing Mike, I never drank coffee... and that was one of the first things he said would never do... Often when we were both in the office and I was scrambling to keep a little ahead of my students, Mike would suggest that I not loose the "big picture" and insist that we go to the "Cellar" in old Ag. Ed. and have coffee. 
I now understand what was really happening: he was teaching a young guy without having it seem like any teaching was actually going on. Mike gave the right amount of encouragement to see people succeed.

I have to tell you, however, I do still hold a little grudge for lost cookies... my dear Grandmother would carefully wrap up and send from Wisconsin her special home-baked Swiss cookies. More than once, I returned to the office to find Mike and John relaxing and sampling the cookies before I had a chance to open them. The two of them were always apologetic, blaming each other, but unrepentant and ready to do it again. It is a terrific memory because of the character of the two of them.

Mike was a very good teacher and influenced my life and others perhaps more than he knew. If only we could all leave memories like that...

I found a little poem that reminded me of Mike. It's called "After Glow." I don't know the author, but wanted to share it with all of you.

$$
\begin{gathered}
\text { I'd like the memory of me } \\
\text { to be a happy one. } \\
\text { l'd like to leave an after glow } \\
\text { of smiles when life is done. } \\
\text { l'd like to leave an echo } \\
\text { whispering softly down the ways, } \\
\text { Of happy times and laughing times } \\
\text { and bright and sunny days. } \\
\text { I'd like the tears of those who grieve, } \\
\text { to dry before the sun } \\
\text { of happy memories } \\
\text { that I leave when life is done. }
\end{gathered}
$$

A true talent in so many ways, I know Mike has left us all with many smiles.

\section{Remarks by Vic Holanda}

"Be the change you want to see in the world" (Gandhi)... Mike shared those words with us on Graduation day, 1975. The following year in June of 1976, I started my career as the Planning Director for the City of Calistoga. My career took to me to the City of Napa, Mendocino County, Stanislaus County, a couple of years in real estate development, six years as Governor Wilson's Director of Permit Assistant (including a tour of duty on the California Coastal Commission), and eventually back here in San Luis Obispo County as the Planning Director in 1999. Returning to "SLO" brought back fond memories as a student at Poly. I even saw Mike a few times at "1865" with Bill Howard or Joe Kourakis. I remember thanking Mike one time over a glass of wine and reminding him what he told me on graduation day.

Back then, there was a recognition ceremony for the graduates in the City and Regional Planning Department, held in the "Patio" (behind "Engineering 21"). I recall mingling with my friends, relatives, and fellow classmates when I bumped into Mike. Mike and I took a short walk down a path, leaving the laughter and conversations behind us. "Well, you did it Vic. Congratulations," he said. I thanked him, but I distinctly remember saying to him, "Now what? All this investment and change in my life and no job prospect." He just smiled the McDougall smile, and said "Change... "Be the change you want to see in the world'...Gandhi said that, Vic. You, my friend, are the one to be that change." Those words and his kind counsel stuck with me all these years, and I must say I am truly grateful for Mike's counsel. 
I recall meeting Mike in my sophomore year. Everyone went through the same program for the first two years. You actually went into your major in your junior year. Back then, I wanted to be an Architect.

We all "survived" the summer quarter (1st year) and were anxious to get started in our second year. Word got around that there were some new instructors coming on board and a new Team Teaching approach was going to be tried.

Joe Kourakis, Ed Ward, and Mike McDougall were the names we heard. All the students were impressed with their credentials and real world experience. Little did we know that they were all going to be very demanding of our time and extremely critical of our work. We soon learned that there was little sympathy and no empathy for creative excuses for late work or incomplete assignments. The expectations were high and competition wide-ranging. The opportunity to "learn by doing" was always there, but individual responsibility and teamwork was a dominant theme. Ken Schwartz, Joe, Frank Hendricks, Ben Polk, Ed Ward, Steve Orlick and others demanded that you deliver your best efforts, but to always work with and help others.

"Second Year Design" was the turning point for all us. If you didn't succeed in "design," chances were you weren't going on to the Architecture program. "Second Year Design" was an extremely demanding program, which pushed your capabilities to the limit. The assignments and "last minute" assignments created an extremely stressful atmosphere. My goal was to become an Architect, but I soon realized that, in order to attain that goal, I had to succeed in all aspects of the math curriculum as well as design. Towards the end of "Second Year" Mike and I had several conversations about my struggles with "Second Year Design" and math, as well as opportunities in Planning. Mike never talked about my weaknesses in architecture; he just talked about how I could apply my talents or as he put it, my unique "character," in the planning profession.

Mike, as far as I can recall, never really criticized anyone. In fact, I don't think he ever said a negative thing about anyone. Anyway, Mike would have these conversations with me about becoming a Planner and how important it was to have vision sustained by moral character. To him, this meant genuine friendship, loyalty, teamwork, cooperation, poise-under-fire, enthusiasm, a competitive spirit, and--above all--self-control. He would say to me, because I was one of the older students, and a service veteran, I had the character and capabilities to lead in the planning profession. Mike was a true gentleman and a mentor who made you work in ways you never thought of working before. He brought out the best in every student. He made the pursuit of continuous improvement a routine that to this day I still practice.

I graduated from a very good Planning program at an outstanding University (Cal Poly), and I have the diploma to prove it. However, it was Mike who in actuality taught me how to become an honorable Planner--in the fullest, most highly perfected manner he knew how--with genuine character.

Although modest and unassuming, Mike was a great teacher, a great mentor, a great example, and a very, very great friend. We who were fortunate to have been his students are better planners and better human beings for having known and studied under him. Over the last 20-some years, his perceptive and insightful counsel during the time I was a naïve and inexperienced student has sustained me through the trials and tribulations of my professional career.

Those words he quoted to me on graduation day: "Be the change you want to see in the world" have made a difference in so many lives, especially mine as a professional planner. Thank you, Mike. 